University for Business and Technology in Kosovo

UBT Knowledge Center

Oct 28th, 9:00 AM - Oct 30th, 5:00 PM

\title{
The Imaret of Mehmed Ali Pasha Preservation and Transformation of an Ottoman and Egyptian Heritage into a Masterpiece of Heritage Protection and Revitalization in Greece
}

Ivkovska Velika

Istanbul Technical University, ivkovska@itu.edu.tr

Follow this and additional works at: https://knowledgecenter.ubt-uni.net/conference

Part of the Architecture Commons

\section{Recommended Citation}

Velika, Ivkovska, "The Imaret of Mehmed Ali Pasha Preservation and Transformation of an Ottoman and Egyptian Heritage into a Masterpiece of Heritage Protection and Revitalization in Greece" (2016). UBT International Conference. 61.

https://knowledgecenter.ubt-uni.net/conference/2016/all-events/61

This Event is brought to you for free and open access by the Publication and Journals at UBT Knowledge Center. It has been accepted for inclusion in UBT International Conference by an authorized administrator of UBT Knowledge Center. For more information, please contact knowledge.center@ubt-uni.net. 
Book of Proceedings

International Conference on Architecture and Spatial Planning

\title{
The Imaret of Mehmed Ali Pasha \\ Preservation and Transformation of an Ottoman and Egyptian Heritage into a Masterpiece of Heritage Protection and Revitalization in Greece
}

\author{
Ivkovska Velika \\ Istanbul Technical University, Istanbul, Turkey \\ ivkovska@itu.edu.tr
}

\begin{abstract}
As part of the Architectural Heritage-Past and Future Challenges for the Region and Architecture Values and Heritage session, I will offer the participants of the $5^{\text {th }}$ IC ASPC 2016 a glimpse at one of the greatest, monumental Islamic structures built in once Ottoman Kavala and still existing with its whole grandeur in today's Greece, The Mehmed Ali's IMARET.

The Imaret külye (complex) of Kavala, built by Mehmed Ali Pasha, an Ottoman general and the future founder of the Egyptian Dynasty, is one of the most outstanding Islamic historical monuments in today's Greece, dominating the view of the old hilly peninsula of the port city of Kavala. Its unique architecture and history, together with the history of its host town, is an incredible example of an immaculate historical preservation and transformation of one exuisite monumental structure, initially built for utilitarian, educational and cosmopolitan purposes, and transformed into one incredible leasure complex and seat of todays Mo.H.A. (Motives for Heritage Acquaintance) Research Center in Kavala, Greece.
\end{abstract}

Keywords: Heritage, Protection of the Cultural Heritage, Historical Preservation and protection, Ottoman, imarets, continuity, past and future traditions, revitalization, Muslim culture, civilizations, Balkans, Greece, Mediterranean, Egypt, Islam in the Balkans, heritage and conflict, endangered heritage

\section{Introduction}

Heritage can be divided into two main categories. On one hand there is the heritage that presents itself in a material, tangible form: archaeology, art, movable objects, architecture and landscape, and on the other, is the form of heritage which arouses the interest of the international community and it is referred to as "Intangible Cultural heritage". This designation was conceived so that certain realities, which remained unseen over a long period of time, and which did not fit in as part of any other established heritage category, could be recognized and taken into consideration. Human creativity goes well beyond the construction of prestigious buildings or the manufacture of precious objects; it also manifests itself through our capacity to create original cultural forms, which are not necessarily material. Thus, cultural expressions such as initiation rites, lifecycle celebrations, etc. testify to the original knowledge practices (concerning nature, social interactions, etc...) as well as to the 
The Imaret of Mehmed Ali Pasha Preservation and Transformation of an Ottoman and Egyptian Heritage into a Masterpiece of Heritage Protection and Revitalization in Greece

accomplishments and knowhow of a given period in time. "Intangible heritage" designates the cultural wealth of a given society, which is complex and should be carefully preserved, for it is even more vulnerable than material heritage, as it is in danger of disappearing with its traditional custodians. ${ }^{5}$ Material and intangible heritage are however closely related. All intangible aspects such as knowledge systems, the principles of action or the values and beliefs of man, can not be considered as heritage if they cannot be shared, and given a sensible form - words, objects, gestures, representations and even behaviors. Also, material or tangible heritage reaches its full significance when it refers to the knowledge and values that constitute its essence, and give meaning to its production. ${ }^{6}$

The architectural heritage includes both physical remnants of the past (i.e., the historic environment in the form of archaeological and architectural sites) as well as nonmaterial aspects of the living past (i.e., intangible heritage as manifested in music, handicrafts, religion, and other rituals and practices). In support of its preservation, authors from a variety of disciplines have noted how such heritage is one of the central, defining aspects of human life, and that it constitutes an important element of people's identity and sense of place. ${ }^{7}$ Implicit in the concept of heritage, however, is the threat that something will be lost unless a conscious effort is made to preserve it. In this regard, scholars typically make a distinction between living culture and heritage, and stress that preservation becomes necessary only when ordinary institutions and cultural practices can no longer guarantee the survival of a site or practice. The mere designation of something as "heritage," then, seems to indicate its end as a living culture/practice. ${ }^{8}$ According to Barbara Kirschenblatt Gimblett, heritage designation gives an endangered site or practice a second life as an exhibition of itself. ${ }^{9}$ A living culture is not only often manifested through and in buildings (tangible heritage), but it may also be the best guarantee for the preservation of the latter. Preservation movements and an interest in heritage sites thus arise as a result of a (perceived) threat to both traditional ways of life and historic buildings.

As a practice, contemporary heritage preservation is heavily dependent on tourism as an economic rationale. And tourism relies on tourist-consumers, a rather unusual type of commodity. In most of its varieties, travel for leisure is valued based on information exchange at the point of sale. This information, usually a combination of linguistic and supporting visual elements, creates, codifies and communicates certain mythical experiences. Whatever medium is used, the language of tourism is one of persuasion and seduction, merging macroeconomic goals with the satisfaction of attributed individual need. ${ }^{10}$

Today, as never before, has the heritage been in such crisis due to global conflicts. At a time when despite our hopes for the peace and progress of humankind, conflicts continue to strike the identity of people through their cultural heritage more ferociously than the worst natural disasters. When the

${ }^{5}$ C. Barillet, T. Joffroy, I. longuEt. Cultural Heritage \& local development; A Guide for African Local Governments. Craterre-ENSaG / Convention France-UNESCO, 2006. pp.9

${ }^{6}$ Ibid. pp. 9

7 See, for example, the sociologist Diane Barthel's Historic Preservation: Collective Memory and Historical Identity (New Brunswick, NJ: Rutgers University Press, 1996); and the geographer Peter Howard's Heritage: Management, Interpretation, Identity (London: Continuum, 2003).

${ }^{8}$ M. Svensson, "In the Ancestors' Shadow: Cultural Heritage Contestations in Chinese Villages," Working Paper No 17, Centre for East and Southeast Asian Studies, Lund University, Sweden, 2006,. Available at www.ace.lu.se.

${ }^{9}$ B. Kirschenblatt-Gimblett, "Intangible Heritage as Metacultural Production," Museum International, Vol.56 No.1-2 (2004), pp.52-64.

10 N.B. Salazar, "Touristifyıng Tanzania: Local Guides, Global Discourse," Annalsof Tourism Research, Vol.33 No.3 (2006), pp.833-52. 
violence abates, a possibility for peace and reconciliation will reopen. Protection of cultural heritage during the conflict can strengthen this possibility, since the heritage bears witness to the inexhaustible progression of civilizations and societies, all of which are precious expressions of a single Humanity. Besides targeting human lives, conflicts have a profound impact on human values, cultures and religions. Increasingly, conflicts target symbols of culture to destroy identities and lead to the deliberate destruction of cultural heritage. ${ }^{11}$

The ethnic, religious, ideological, territorial, governmental and economic international conflicts are great threat for the world heritage. Due to these ideological conflicts and conflicts of interests we have lost, and are facing the danger of losing heritage. Today when almost the whole world is a battle field, the heritage is also one of its victims. Conflicts create dissolution of countries a process that creates heritage inherited issues. Numerous are the examples of the heritage in conflict zones. We do not need to further from the Balkans and see those issues in practice. The disintegration of Yugoslavia led to such examples ${ }^{12}$ as well as within the new countries that were later formed. ${ }^{13}$ But the heritage is not only endangered because of the war conflicts because the threat does not end when the war or conflict ends. Because of the nationalist politics the heritage continues to be endangered. This is an example of the modern, recent history. The case with the Ottoman Empire is not exclusion as well. Since the Empire dissolved, new countries were formed and the inherited heritage was left in management of the new nations where each dealt with it in their own manner but the common thing is that we tend to neglect the heritage of the previous establishments, identify it as foreign and as a reminder of a bad past and tend to leave it to decay or try to completely erase it. $^{14}$

\section{Historical Development of Kavala}

The town of Kavala was first mentioned in the $7^{\text {th }}$ century BC by the name of Neapolis, the new city, a colony of the people of Thassos, and then as a strong, independent city and a member of the large Athenian League. During the time of the Macedonian dynasty, King Philip, the father of Alexander the Great, annexed it from Athens and it became a port of his stronghold at Philippi. During the Roman period it became a major port and a much frequented staging port on via Egnatia. Neapolis was founded on a headland projecting into the sea which could be easily fortified. The name of the town was later changed to Christopolis. ${ }^{15}$ Towards the end of the $14^{\text {th }}$ century Christoupolis was conquered and burnt

${ }^{11}$ S. De Caro, "Protecting Cultural Heritage in Times of Conflict", Contributions from the participants of the International course on First Aid to Cultural Heritage in Times of Conflict, ICCROM (2010), pp. VI

12 The attack on Dubrovnik city walls, the destruction of the 427 year old bridge in Mostar are only few of the examples of heritage suffering a civil war.

13 When Kosovo declared its independence from Serbia in 2008 the inherited heritage from the Orthodox Serbs was a target from the non-Christian population and was being damaged.

${ }^{14}$ In Greece, most of the Ottoman mosques have been leveled to ground while those who still exist were either left abandoned or transformed into churches. One thing they all have in common is that all the minarets have been leveled to ground or to its foundations.

${ }^{15}$ Kavala one destination, a kaleidoscope of experiences, Gazette of Municipality of Kavala 
The Imaret of Mehmed Ali Pasha Preservation and Transformation of an Ottoman and Egyptian Heritage into a Masterpiece of Heritage Protection and Revitalization in Greece

down by the Ottomans and for some time the site has been abandoned. The earliest mention of a village/town named Kavala, positioned on the site of Byzantine Christoupolis, was found in an Ottoman

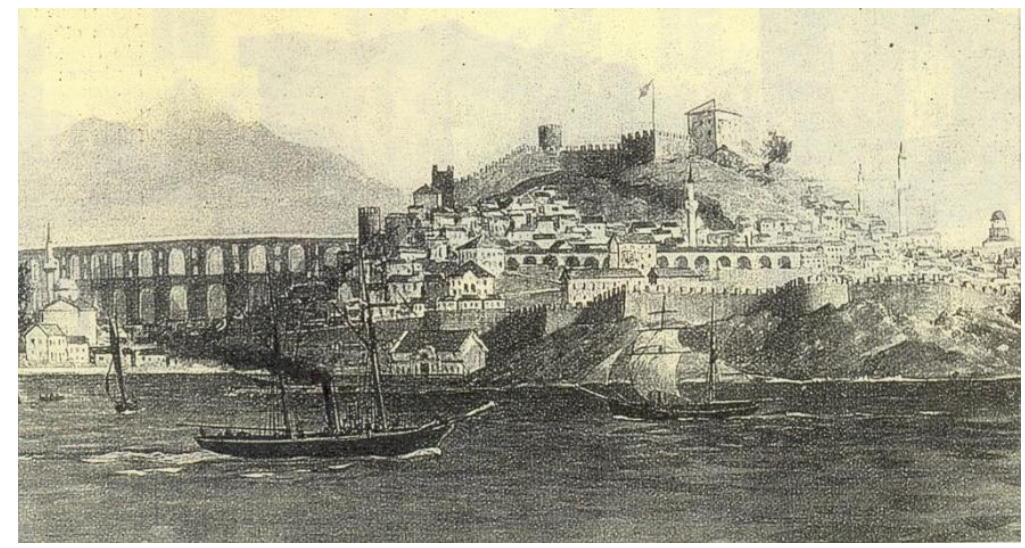

tax register (tahrir defter) completed in the year 1478 (h.883). ${ }^{16}$

Fig.1 Old drawing of the Panagia peninsula with the Imaret and the aqueduct

Three important milestones mark the importance of Ottoman Kavala since the town fell under the Ottoman rule [Fig.1]. The first milestone was the period when Ibrahim Pasha, the Sultan Suleiman's Grand vizier, made major construction structures towards developing the life in the city and the Panagia peninsula where the old historic nucleus of Kavala is located. He rebuilt the aqueduct on the foundations of the Byzantine one [Fig.2], built the mosque, the hamam and the soup kitchen. After the Greeks took over the town in 1912, his mosque was converted in the church of Saint Nicholas. [Fig.3]

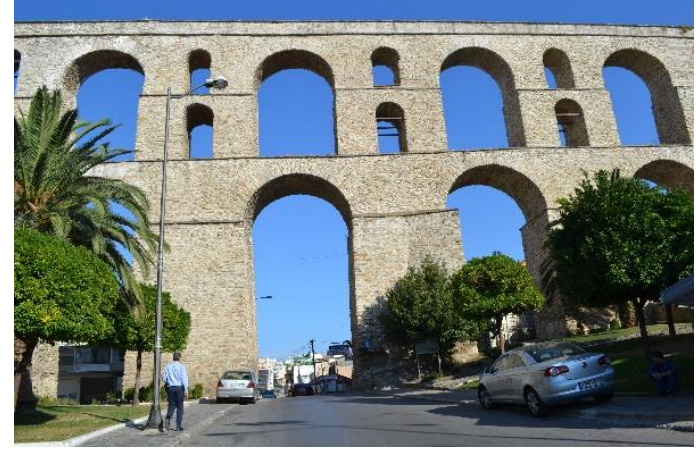

Fig.2 Kavala Aqueduct

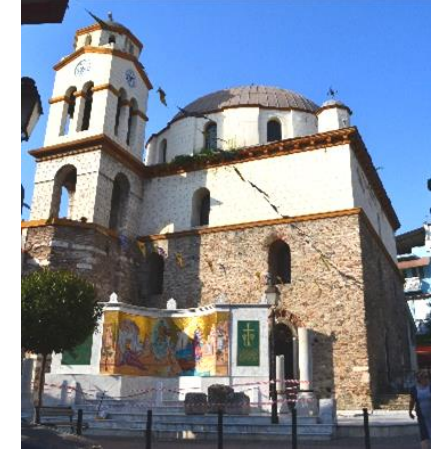

Fig.3 St. Nicholas Church

The second milestone that marked the importance of the Ottoman town of Kavala was the era of Mehmed Ali, the founder of Modern Egypt (17 May 1805 - 2 March 1848). In his time the Imaret, as his pious foundation was built, the town flourished and many other mosques were built.

16 Lowry W.H. 2008. The shaping of the Ottoman Balkans 1350-1550. Bahcesehir University Publications. Istanbul 
The third milestone of Ottoman Kavala was the industrial boom that happened by the end of the $19^{\text {th }}$ century. It was the development of the tobacco industry that made a strong impact toward the future development of the town.

\section{Mehmed Ali Pasha}

Mehmed Ali Beğ (later: Paşa), Muhammad Ali Pasha (Arabic: محمد علب باش ) or Mehmet Ali Paşa (Kavalalı Mehmet Ali Pasha in Turkish) was born in the small Aegean port town of Kavala in Ottoman Rumelia, the European part of the Ottoman Empire, in the year 1184 Hicri (August 27, 1771- April 17, 1771). ${ }^{17}$ How this man crossed the Mediterranean Sea to Egypt, how he established himself as ruler of this important Ottoman province for almost half a century, and how he founded a dynasty there that ruled for a hundred years after his death- all these events add up to a fascinating story. Mehmed Ali was to become one of the most remarkable men in modern Islamic history. ${ }^{18}$

The period of Mehmed Ali's reign, which started in 1805 when he was appointed by the Ottoman Sultan as wali of Egypt and ended in 1848 with his deposition as a result of mental illness, offers one of the most interesting epochs of modern Egyptian history. During this period Egypt, while still forming a pan of the Ottoman Empire, assumed an increasingly independent stance, and was finally granted as a hereditary domain to Mehmed Ali by the Sultan 'Abd al-Majid in 1841. The Pasha, as Mehmed Ali came to be known in Egypt (or the Viceroy, as he was commonly known to Europeans), managed in a long and effective reign to bring to an end the Mamluk power in Egypt and to create in its stead a loyal elite composed of members of his own family, of friends and acquaintances from his home town of Kavala, and of members of the expanding bureaucracy that he founded in Egypt. Moved by a desire to turn his tenure as governor into a more secure and permanent position, Mehmed Ali undertook various radical measures that changed Egypt's position within the Ottoman Empire, strengthened its economic ties with Europe at the expense of older links with other provinces of the empire, and radically changed its social and cultural map.

Growing up in Kavala, a small town with a population of no more than 3000 inhabitants at the end of $18^{\text {th }}$ century, ${ }^{19}$ it appears that Mehmed Ali received no formal education, as well as his own acknowledgment of being illiterate until the age of forty seven (1817-1818) when he had learned to read and write..$^{20}$

Was it the reason for him being illiterate for so long, adding the fact that he was taunted by his playmates in early childhood for this same reason, made him focused to expend enormous energy and resources in creating educational infrastructure in his hometown.

\section{Architectural layout of the Imaret}

17 K.Fahmy. Mehmed Ali: From Ottoman Governor to Ruler of Egypt. Oxford (Oneworld Publications), 2009, pp.2-3

${ }^{18}$ Ibid, pp. $1-2$

${ }^{19}$ Kiel, 2000, p.61 quotes the French traveler Felix Beaujour who visited Kavala in 1799 and gives maximum numbers of its inhabitants as 3000

20 K.Fahmy. Mehmed Ali: From Ottoman Governor to Ruler of Egypt. Oxford (Oneworld Publications), 2009, pp.5 
The Imaret of Mehmed Ali Pasha Preservation and Transformation of an Ottoman and Egyptian Heritage into a Masterpiece of Heritage Protection and Revitalization in Greece

Mehmed Ali was a great benefactor to his hometown, establishing the foundation (vaklf), which between years h.1223-h.1236 (1808-1821 $)^{21}$ resulted with the construction of a large complex of buildings. Located in the Panagia peninsula of Kavala (the old historic nucleus) with a view of the bay and the port of the town, positioned below the fortress in the lower walled portion of present day Kavala, the Imaret stands with its imposing series of interconnected buildings endowed and built by Mehmed Ali Pasha. [Fig.4]

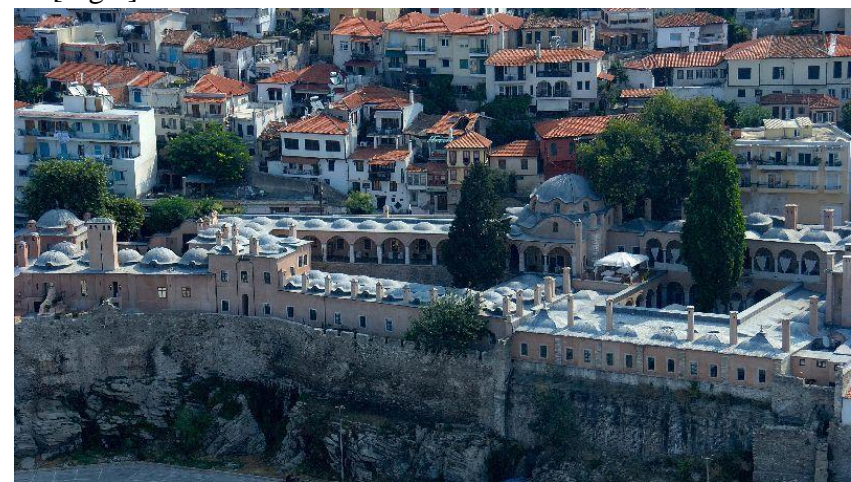

Fig.4 View of the Imaret complex (source: http://tourism.kavala.gov.gr/web/guest/worthseeing)

The architecture of the Imaret presents the classic example of the $19^{\text {th }}$ century "Ottoman Baroque" architecture and, as the Ottoman architectural historian, Ekrem Hakki Ayverdi, first pointed out, more than a little reminiscent of the architecture of the Zeynep Sultan Camii [Fig.5], which stands across the street from Istanbul's Gulhane Park. ${ }^{22}$ Built in stages, when completed the complex included: two high schools (medreses), thirty six dormitory rooms, a library, a soup kitchen, a mosque, two class rooms (dershane) [Fig.6], pavilion, bathhouse (hamam) and administrative offices. ${ }^{23}$
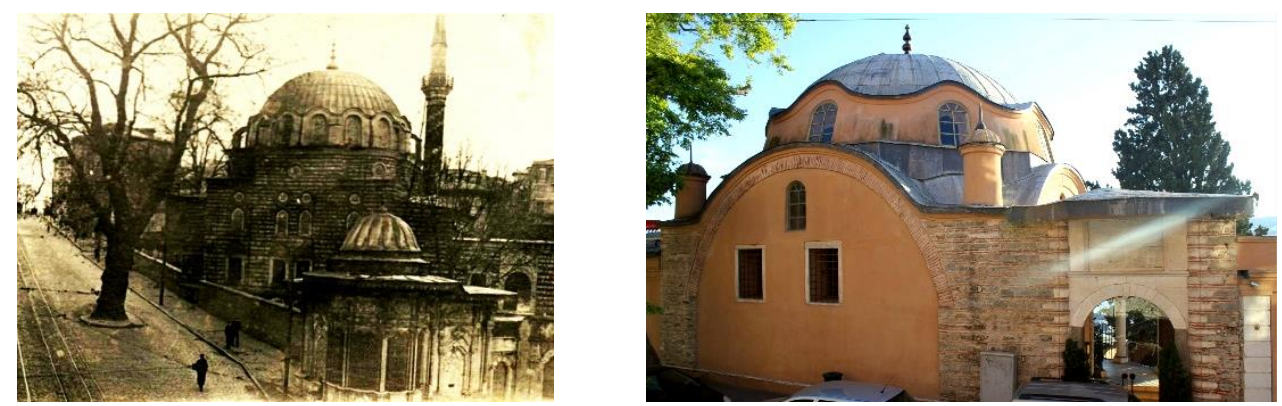

Fig. 5 Zeynep Sultan Mosque Istanbul (source: eski.istanbulium.net) Fig.6 The dershane in Imaret complex (source: www.serhira.blogspot.mk)

${ }^{21}$ Lowry W.H. 2009. In the Footsteps of the Ottomans. Bahcesehir University Publications. Istanbul. pp. 142

22 Lowry, H.W. 2011. Remembering One's Roots, Mehmed Ali Pasa of Egypt's Links to the Macedonian Town of Kavala. Bahcesehir University Publications. Istanbul. pp.15

${ }^{23}$ Stefanidou A. 1987. The Kavala Imaret. Macedonian Chronicles, 25, pp.203-265. 
Book of Proceedings International Conference on Architecture and Spatial Planning

The Imaret complex was integrated in the structure of the old city. It followed the traditional introvert internal spatial arrangement and it was adapted to the physical environment. [Tab.1]

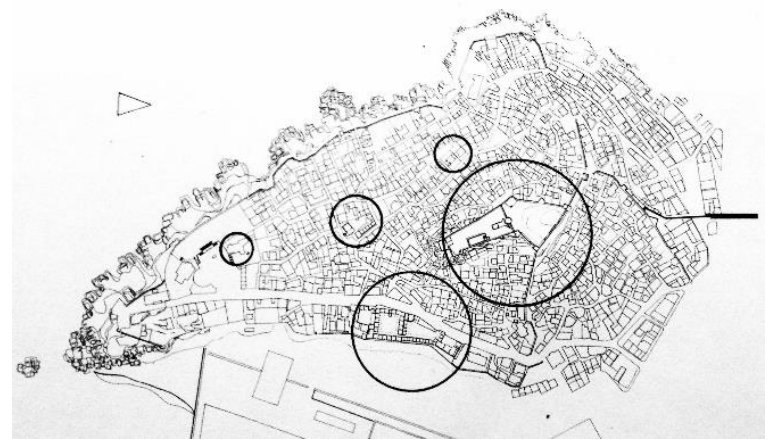

Tab.1 Imaret in the urban fabric, bottom circle (source: Kavala Intra Muros: Spatial readings and Architectural Proposals, Demos Kavala, 1992)

It consisted of four parts positioned in a row, and each part was organized around internal patio. Starting from the north side, the first structure was the soup kitchen (imaret) with the secondary school (mekteb) in the northeast corner. Following up the one medrese with the main classroom (dershane) in the southeast corner, and next to it was the second high school (medrese) with the second dershane in the northeast corner and the "wet" spaces in the south side. ${ }^{24}$ The offices of the administration of the vakif were located at the south end. [Tab.2] The dershane [Tab.3] and the mekteb were given somewhat higher emphasis by highlighting the units by the special attention paid to their domes. The walls of Imaret complex were built of carved stones and scattered bricks up to the point where arcs and domes started to be formed. From there on, construction was made exclusively by bricks. ${ }^{25}$

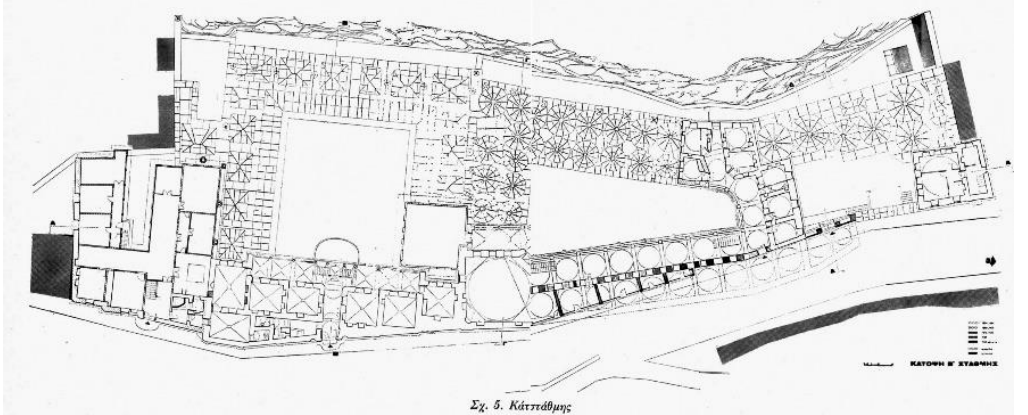

Tab.2 First floor of the Imaret complex (source: The Kavala Imaret Stefanidou A. 1987)

\footnotetext{
${ }^{24}$ Lalenis K. Samourkasidou E. 2013. Wakf in Kavala, Greece: A legal, Political and Architectural Heritage Issue. Archnet-IJAR, Vol.7-issue 2. pp.214

${ }^{25}$ Ibid. pp. 214
} 
The Imaret of Mehmed Ali Pasha Preservation and Transformation of an Ottoman and Egyptian Heritage into a Masterpiece of Heritage Protection and Revitalization in Greece

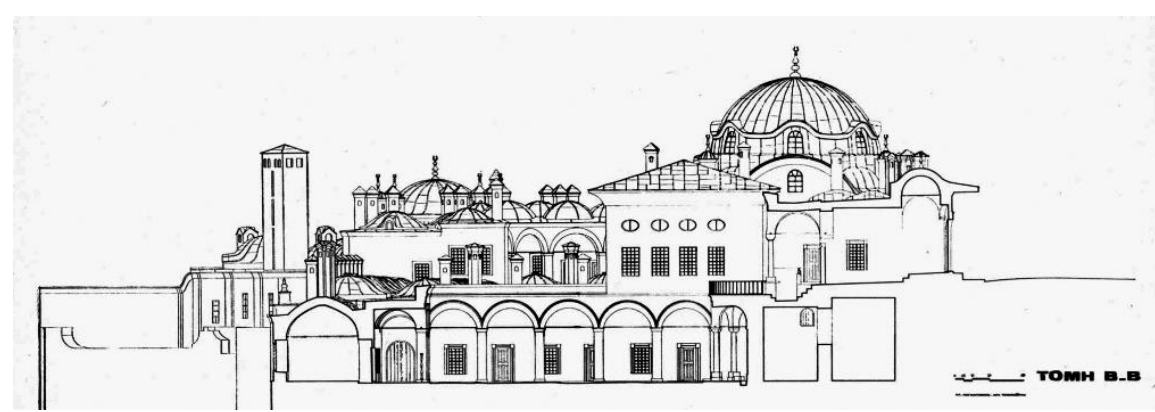

Tab. 3 Section of the second medrese with view on the, now lost, second dershane (source: The Kavala Imaret Stefanidou A. 1987)

The Imaret complex (külye) was distinguished for its simplicity in its structural geometric elements, and in the decoration of external and internal facets. The most exiting architectural elements were the internal patios and the continuous succession of closed, semi hypaethral [Fig.7], and open air spaces, with the equivalent gradual shadings. ${ }^{26}$ [Fig.8]
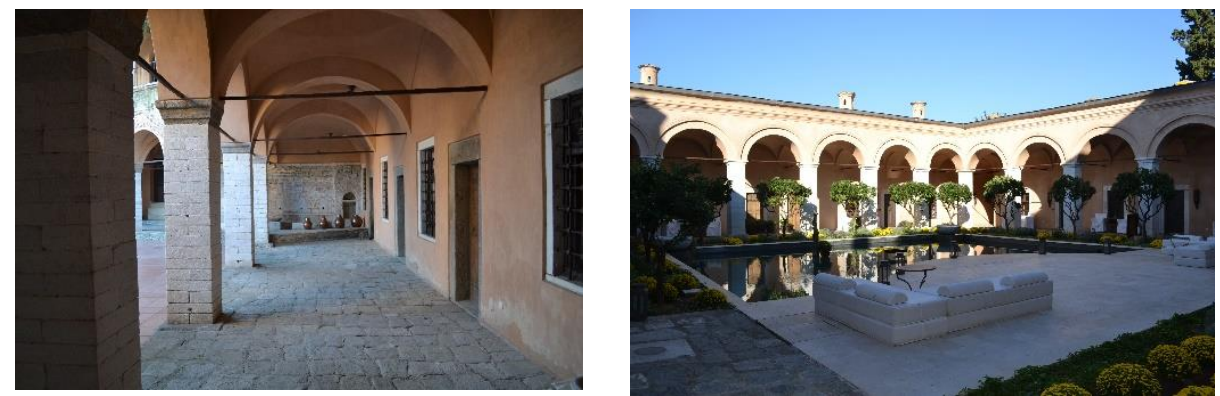

Fig. 7 The arched porticos of the medreses (source: Velika Ivkovska, 2016)

Fig. 8 The pool in the first courtyard. (source: Velika Ivkovska, 2016)

What makes the külye unique, is not only the fact that it was built later than most such foundations in the Ottoman era, but, also that it was so clearly intended to serve exclusively as an educational center. ${ }^{27}$ The appearance of two medreses, one a theological seminary (medrese) and the other as school of engeneering (mühendishane), together with a sibyan mektebi (primary school for teaching the Qu'ran), and a second mekteb (secondary school), virtually under the same roof [Fig.9], is unprecedent in Ottoman practice, but when one takes into account that all the other structures, whether to be the lecture hall, the library, the soup kitchen, the bath house, etc., were all built with one purpose, namely to serve the needs of the students and their teachers, it is clear that Mehmed Ali's focus was on meeting the educational needs of his former fellow Muslim townsmen. ${ }^{28}$

${ }^{26}$ Lalenis K. Samourkasidou E. 2013. Wakf in Kavala, Greece: A legal, Political and Architectural Heritage Issue. Archnet-IJAR, Vol.7-issue 2. pp.215

27 Lowry, H.W. 2011. Remembering One's Roots, Mehmed Ali Pasa of Egypt's Links to the Macedonian Town of Kavala. Bahcesehir University Publications. Istanbul. pp.16

${ }^{28}$ Ibid, pp. 16 
Book of Proceedings International Conference on Architecture and Spatial Planning

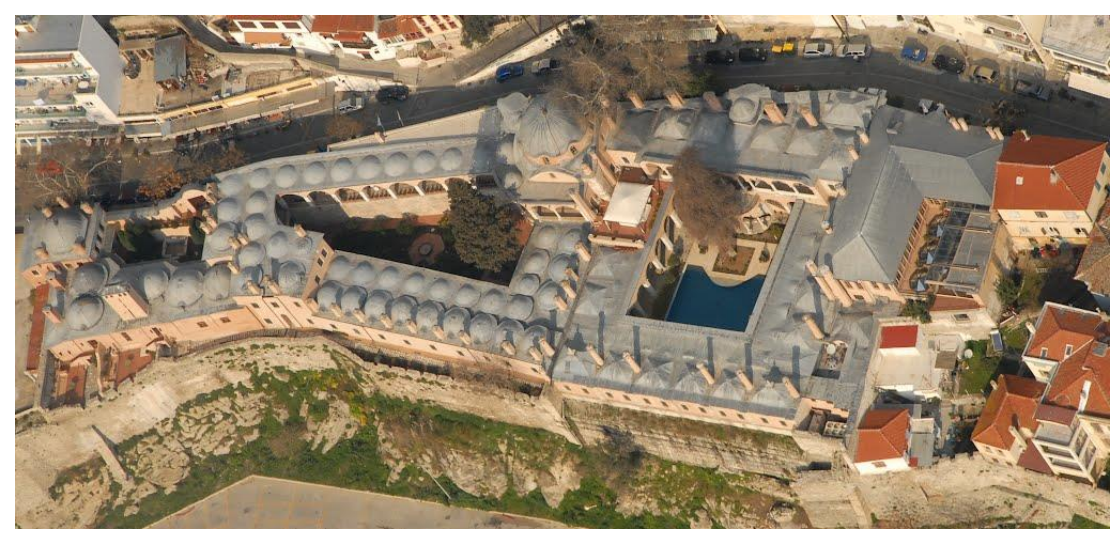

Fig 9. Areal view of the Imaret complex today (source:www.greece.com)

\section{Ownership}

Vakifs with their pious purpose, tended to the good of mankind, as to support a mosque or caravansaray, to provide for support of one's family, or neighbors, to benefit some person or the poor, etc. With their classification to the categories for fulfilling the noble and charitable scope for which they were established such as structures used for schools, mosques, hospitals etc. and the profitable endowments, whose income was used to support other sub categories such as real estate, land parcels and vakif property they were all established as a means of the upper social classes to support the poor. ${ }^{29}$ They contributed in the economic prosperity of a city, since they participated in the construction of the urban structures, created new jobs, assisted in improving conditions of public health and safety. They were a crucial factor for the quality of life in a city and for its competitiveness ${ }^{30}$

The legal story of the Kavala vakif and the Imaret complex being part of it, started when Mehmed Ali became Pasha of Egypt in 1811 when the Ottoman Sultan Mahmud II offered him the vakif for his good services. ${ }^{31}$ The vakif of Kavala was legally established in 30 March $1813 .{ }^{32}$ Later under Ottoman suzerainty as well as under British protection, the Khedive ${ }^{33}$ of Egypt became owner of the pious foundation of the region and even though the Ottomans took over the political control of the area, the

${ }^{29}$ Lalenis K. Samourkasidou E. 2013. Wakf in Kavala, Greece: A legal, Political and Architectural Heritage Issue. Archnet-IJAR, Vol.7-issue 2. pp.206,207

${ }^{30}$ Lykourinos K. 2005. Kavala in Ottoman period (end of $14^{\text {th }}$ century-1912)- the old city- The quarter of Panagia. Publication of the Cultural Association of Panagia. Kavala. pp.

31 Tsitselikis K. 2012. Old and New Islam in Greece: From Historical Minorities to Immigrant Newcomers. Martinus Nijhoff Publishers. pp.356

${ }^{32}$ Vakalopoulos A. 1952. Thasos: son histoire et administration de 1453 à 1912, Paris. Doc.16

${ }^{33}$ a title largely equivalent to the English word viceroy. It was first used, without official recognition, by Mehmed Ali Pasha the governor of Egypt and Sudan, and vassal of the Ottoman Empire. The initially self-declared title was officially recognized by the Ottoman government in 1867 when Sultan Abdul Aziz II granted the title to Ismail Pasha of Egypt 
The Imaret of Mehmed Ali Pasha Preservation and Transformation of an Ottoman and Egyptian Heritage into a Masterpiece of Heritage Protection and Revitalization in Greece

Egyptian still managed the vakıf. ${ }^{34}$ When Greece annexed Macedonia the vakif was respected according to the Greek-Turkish Treaty of $1913 .{ }^{35}$ A year later Egypt was officially proclaimed a British protectorate and the question whether Egypt was under Ottoman or British sovereignty became critical importance for the legal fate of the vakifs of Kavala and Thassos. ${ }^{36}$

The complex continued to function as such until it came under Greek control in September 1913 during the course of the Second Balkan War. Thereafter, it was put to a variety of purpose (following the population exchange with Turkey in 1923 it was used to house refugees for decade). ${ }^{37}$ The ownership was formally ceded to the Government of Egypt since it was part of the vakif that was inherited by Egypt when it proclaimed its independence in 1922, and officially stopped operating in June 1924. Having parts demolished for urban interventions (part of Imaret was demolished in 1931 in order for the adjacent street to be widened), hosting refugees, being sealed in 1967 after the military junta sized power in Greece and ordered the residents (mostly refugees) to leave and being abandoned for decades, ${ }^{38}$ [Fig.10] Imaret's long legal "battle" for its ownership ended on 1 August 1984, after long bilateral negotiations between Greece and Egypt, when an accord was signed on the property status of the vakıfs. This agreement divided the vakıfs into categories, when the vakıf of Kavala and Thassos was put under Greek ownership in return for financial compensation, but the house of Mohamed Ali and the Imaret, both in Kavala, were to remain under Egyptian ownership for historical reasons. ${ }^{39}$ The Greek government granted the Imaret status as a historical building. ${ }^{40}$
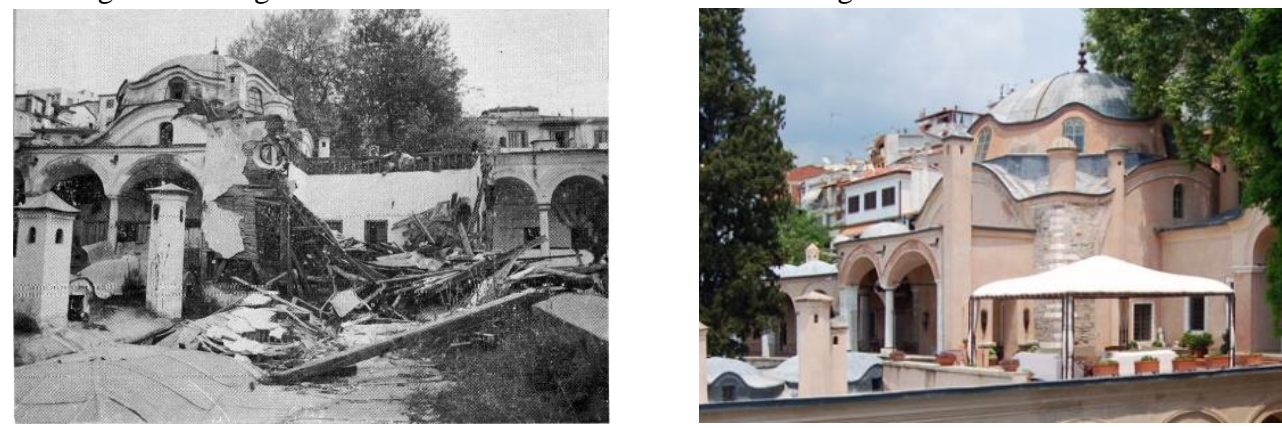

Fig.10 The debris of the second dershane in 1980 (source: The Kavala Imaret Stefanidou A. 1987)

Fig.11 Condition of the dershane after the restoration of the complex (source: www.yatzer.com)

This was the situation into the mid 1990's when an enterprising lady from Kavala named Anna Missirian Tzouma managed to convince the Egyptian Government to grant her a long term lease so that the complex might be restored as a boutique hotel. Many years (and great deal of money) later,

${ }^{34}$ Tsitselikis K. 2012. Old and New Islam in Greece: From Historical Minorities to Immigrant Newcomers. Martinus Nijhoff Publishers. pp.356

${ }^{35}$ Ibid. pp.356

${ }^{36}$ Ibid. pp.356

${ }^{37}$ Lowry. 2009. pp.142

${ }^{38}$ Lalenis K. Samourkasidou E. 2013. Wakf in Kavala, Greece: A legal, Political and Architectural Heritage Issue. Archnet-IJAR, Vol.7-issue 2. pp.211,212

${ }^{39}$ Tsitselikis K. 2012. Old and New Islam in Greece: From Historical Minorities to Immigrant Newcomers. Martinus Nijhoff Publishers. pp.358

${ }^{40}$ Ibid. pp.358 
Book of Proceedings

International Conference on Architecture and Spatial Planning

following a meticulous restoration (under the strict control of the Kavala Ephorate's architects), it reemerged as the "Imaret", a world class boutique hotel. ${ }^{41}$

In 2004, after 22-month restoration, Imaret reemerged as the first boutique hotel in Greece to be housed in historic building. The cost of restoration reached to 7 million Euros and the restoration managed to retrieve the initial image of the monument. ${ }^{42}$

The hotel hosts 30 luxurious rooms (previous students dormitory rooms), decorated with Egyptian chandeliers and antique kilims on the stone floors. The main dershane[Fig.11] was readapted and converted to a library while the old cistern was transformed to an internal pool. The hotel is also equipped with a restaurant overlooking the beautiful port and town of Kavala, while the inner courtyards [Fig.12] host fountains and beautiful citrus trees.[Fig.13]
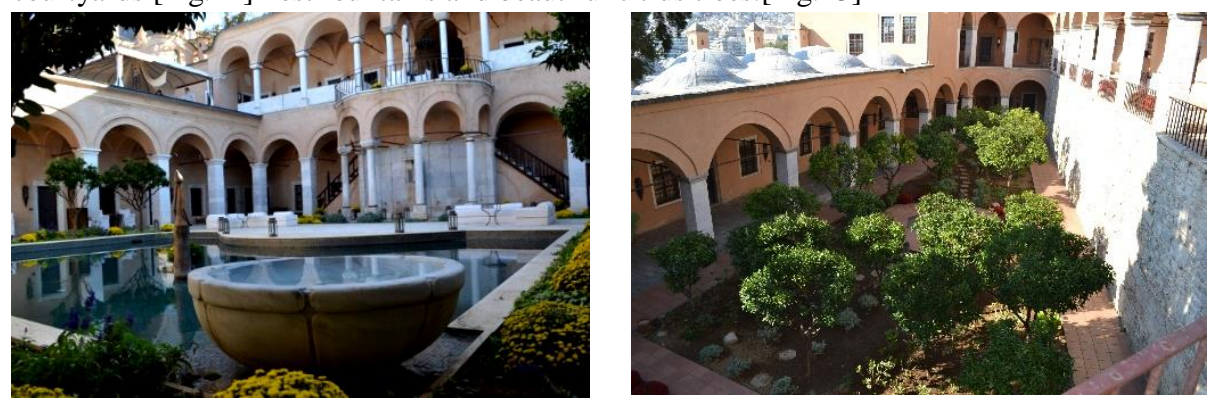

Fig.12 First courtyard of the Imaret (source: Velika Ivkovska, 2014)

Fig.13 The citrus trees courtyard (source: Velika Ivkovska 2014)

The greatness of the Imaret today, besides being transformed into one of the most exquisite hotels, is that it is home to the I.M.A.R.E.T. (Institute of Mohamed Ali for the Research of the Eastern Tradition) NGO and Mocha. (Motives for Heritage Acquaintance) Research Center. I.M.A.R.E.T's objectives are cultural cooperation between Greece and Egypt and more specifically between Kavala and Alexandria. Its objectives also include the research on manuscripts of the library of Alexandria, related to the Egyptian presence in Kavala and the operation of Imaret, organizing conferences, exhibitions, lectures, etc.

Mocha is a Greek private non-profit, non-governmental Research Center supervised by General Secretariat for Research and Technology (GSRT) of the Greek Ministry of Culture, Education and Religious Affair. Mo.H.A. aims to realize, support, promote and disseminate research and development projects and events, which correspond to the Islamic world, as well as to the interaction of this world with other universal political, geographical and cultural environments. These projects derive from the departments of Humanities and Social Sciences, Science, Environment, Culture and Art.

\footnotetext{
${ }^{41}$ Lowry W.H. 2009. In the Footsteps of the Ottomans. Bahcesehir University Publications. Istanbul. pp. 142

${ }^{42}$ Lalenis K. Samourkasidou E. 2013. Wakf in Kavala, Greece: A legal, Political and Architectural Heritage Issue. Archnet-IJAR, Vol.7-issue 2. pp.216
} 
The Imaret of Mehmed Ali Pasha Preservation and Transformation of an Ottoman and Egyptian Heritage into a Masterpiece of Heritage Protection and Revitalization in Greece

\section{Conclusion}

Culture is an important factor in socio-economic development. Investing in cultural heritage not only supports employment during restoration work but also has a direct impact on the growth of cultural tourism. This brings long-term social and economic benefits, especially to local communities. Preserving and revitalizing cultural and natural heritage are crucial in promoting the sustainability of local communities and increase public accessibility.

The obligation to conserve the architectural heritage of our local communities is as important as our duty to conserve the significant built heritage and its values or traditions of previous eras. More than ever, architectural heritage everywhere is at risk from a lack of appreciation, experience and care. Some have already been lost and more are in danger. It is a living heritage and it is essential to understand, define, interpret and manage it well for future generations.

The Mehmed Ali' Imaret was facing this same risk, after being mistreated and abandoned for decades. Thanks to the strong will, effort and the vision that one person had (Mrs. Anna Misirian) Imaret was saved from an inevitable future of being completely lost.

The exceptional way of transforming the use of the structure from its primal purposes into its future, and yet again humanistic goals, aims at exploring and researching the achievements of Muslim culture and civilization before the dawn of modernity and its impact on our today world. This "intervention" only adds to its outstanding purpose of continuity. The külye of Kavala stands as a symbolical example of bridging the challenges that this structure went through to preserve its past and future, both architectural, humanistic, and in a way, spiritual continuities in the Balkans. By sustaining it, this heritages past was given a future.

No better words can be used as a conclusion for the importance and significance of Imarets work than its owner's, the woman who brought back not just its long lost glory but also its future invaluable tangible and intangible purpose and essence.

"When viewing history free of preconceptions, we realize that the cast of characters who built the global scale of knowledge that we enjoy today, is broader than what we have been taught. One particular aspect of human history that is somehow overlooked is the contribution of the Islamic civilization to the shaping and development of the Western thought. Equally descending from the Antiquity, the Islamic civilization existed not only in geopolitical rivalry but also in economic cooperation and cross-fertilization with the Mediterranean cultures. This extraordinary civilization was developed in the part of the world that stretched from Spain to China, registering one of the most important paths in the culture of scientific evolution of man. Great scientists, man and woman of Islam, who for centuries studied the works of ancient civilizations but more over discovering new methods, they produced positive and innovative work that laid the foundation for the development of the West in the form we know today, contrasting the dark ages of Europe with the Golden Age of Islam.

The MO.H.A (Motives for Heritage Acquaintance) Research Center strives to Research the history and interaction of the pre-Renaissance Mediterranean civilizations and reinsert through educational initiatives the Islamic contributions upon the scientific, technological and cultural heritage of our modern world. At a time of increasing xenophobia and extremism, we believe that mutual recognition, acceptance, and respect between people, is the only way to counter violence and 
Book of Proceedings

International Conference on Architecture and Spatial Planning

fanaticism that stand in the way of progress and development and I invite you to share our vision."

Anna Missirian Tzouma

\section{References}

1. Barillet, C., Joffroy, T., longuet, I.: Cultural Heritage \& local development; A Guide for African Local Governments. Craterre-ENSaG / Convention France-UNESCO, (2006)

2. Barthel, D.: Historic Preservation: Collective Memory and Historical Identity (New Brunswick, NJ: Rutgers University Press, (1996)

3. Howard, P.: Heritage: Management, Interpretation, Identity, London, Continuum, (2003)

4. Svensson, M.: In the Ancestors' Shadow: Cultural Heritage Contestations in Chinese Villages, Working Paper No 17, Centre for East and Southeast Asian Studies, Lund University, Sweden, (2006)

5. Kirschenblatt-Gimblett, B.: Intangible Heritage as Metacultural Production, Museum International, Vol.56 No.1-2 (2004)

6. Salazar, N.B.: Touristifyıng Tanzania: Local Guides, Global Discourse, Annalsof Tourism Research, Vol.33 No.3 (2006)

7. De Caro, S.: Protecting Cultural Heritage in Times of Conflict, Contributions from the participants of the International course on First Aid to Cultural Heritage in Times of Conflict, ICCROM, (2010)

8. Kavala one destination, a kaleidoscope of experiences, Gazette of Municipality of Kavala

9. Lowry, W.H.: The shaping of the Ottoman Balkans 1350-155, Bahcesehir University Publications, Istanbul, (2008)

10. Fahmy, K.: Mehmed Ali: From Ottoman Governor to Ruler of Egypt, Oneworld Publications, Oxford, (2009)

11. Lowry, W.H.: In the Footsteps of the Ottomans, Bahcesehir University Publications, Istanbul, (2009)

12. Lowry, H.W.: Remembering One's Roots, Mehmed Ali Pasa of Egypt's Links to the Macedonian Town of Kavala, Bahcesehir University Publications, Istanbul, (2011)

13. Stefanidou, A.: The Kavala Imaret. Macedonian Chronicles, 25, (1987)

14. Lalenis, K., Samourkasidou, E.: Wakf in Kavala, Greece: A legal, Political and Architectural Heritage Issue, Archnet-IJAR, Vol.7-issue 2, (2013)

15. Lykourinos, K.: Kavala in Ottoman period (end of 14th century-1912) - the old city- The quarter of Panagia, Publication of the Cultural Association of Panagia, Kavala, (2005)

16. Tsitselikis, K.: Old and New Islam in Greece: From Historical Minorities to Immigrant Newcomers, Martinus Nijhoff Publishers, (2012)

17. Vakalopoulos, A.: Thasos: son histoire et administration de 1453 à 1912, Doc.16, Paris, (1952)

18. http://www.moha.center/index.php/about-moha/objectives 